\title{
Satisfying Deficiency Needs in the Poetry of Adrienne Rich, Nikki Giovanni, and Leslie Marmon Silko
}

\section{by: Dina Mohamed}

Abraham Maslow (1908-1970) is one of the most influential American psychologists of the twentieth century. $\mathrm{He}$ is one of the founders of humanistic psychology, which is mainly concerned with studying healthy individuals and understanding human behavior through investigations of meanings, values, human potential, and self-actualization. Maslow's hierarchy of needs is considered as a fundamental approach in the study of human motivation. It assumes that human beings pass through many developmental stages in their evolution toward self-actualization. The hierarchy entails that human beings are born with a set of human needs that must be fulfilled to achieve psychological health. Maslow's hierarchy includes five motivational levels, which are arranged in an ascending order as follows: physiological needs, safety needs, belonging and love needs, self-esteem needs, and finally self-actualization need.

This study involves an analysis of the poetic works of three American poetesses: Adrienne Rich (1929-2012), Nikki Giovanni (1943- ), and Leslie Marmon Silko (1948- ) in the light of Abraham Maslow's hierarchy of needs, particularly the deficiency needs. Rich, Giovanni, and Silko come from the American society that guarantees a full 
satisfaction of the physiological needs for its people. Therefore, this study begins with exploring the security needs, moving to the love and belonging needs, and finally the esteem needs in their poetry. Each of these needs will be discussed point by point for each poetess, highlighting the points of similarity and difference. The poetesses under study tackle common themes, but due to their different races and historical backgrounds, they satisfy the deficit needs in different ways. They reflect similar forms of insecurities in the American society, such as male domination, suppression of women, racial discrimination, and poverty. It is worth noting that Giovanni and Silko concentrate much on the issue of racial discrimination, which particularly faces their people. Moving to the next level in the hierarchy, Rich satisfies her needs for love and belonging to women and children, while Giovanni fulfills those needs in the sphere of the family and the African-American community, meanwhile Silko finds solace in nature and with animals. Last but not least, the poetesses meet the esteem needs by acknowledging their worthiness and abilities. Not only do they possess high selfesteem, but they also pay tribute to the accomplishments of the heroic figures of their different communities. By fulfilling the security, love and belonging, and esteem needs, Rich, Giovanni, and Silko emerge as vigorous individuals who make the world in which they live a better place because of their reliable endeavors . 


\section{Maslow's Hierarchy of Needs}

As stated earlier, Maslow's hierarchy of needs is a continual dynamic process of satisfying needs. Maslow illustrates :

It is quite true that man lives by bread alone - when there is no bread. But what happens to man's desires when there is plenty of bread and when his belly is chronically filled? At once other (and higher) needs emerge and these, rather than physiological hungers, dominate the organism And when these in turn are satisfied, again new (and still higher) needs emerge and so on. (Motivation 38(

This means that once a need is partially satisfied, it no longer dominates behavior and another need arises to take its place .

The physiological needs are the basic needs which are essential for the survival of the organism. They include the need for air, water, oxygen, fats, proteins, stable body temperature, sex, and shelter. Once the physiological needs are sufficiently met, safety needs come to the foreground. Maslow mentions that safety needs comprise the desire for "security; stability; dependency; protection; freedom from fear, from anxiety, and from chaos; need for structure, order, law, limits; strength in the protector, and so on" (Motivation 39). The gratification of the safety needs leads to the emergence of a new set of needs, known as love and belonging needs. In this stage, persons long for having intimate relations with people and finding a place in their 
groups or families. Life partners, friends, or children are all significant sources of love and belonging .

The next level which appears after satisfying love and belonging needs is concerned with esteem needs. Maslow classifies the esteem needs into two sets: self-esteem and esteem from other people. The self-esteem needs include such needs as desire for confidence, competence, mastery, accomplishment, and independence Together with this is a desire for gaining respect of others, which generally comprises the desire for recognition, dominance, attention, acceptance, and appreciation .Maslow also assures that healthy self-esteem is centered on deserved esteem from other people rather than on external eminence or fame (Motivation 45 .)

When all the previous basic needs are fulfilled, the need for self-actualization develops. While the first four basic needs are 'deficit needs', 'self-actualization' is a 'growth need' that depends on one's desire to grow and develop. Maslow defines this need as the desire "to become everything that one is capable of becoming" (Motivation 46). Self-actualization is the ability of the individuals to realize and exploit their potentials to the fullest and achieve what they are capable of. The need for self-actualization differs from all other needs: individuals do not stay content when fulfilling it; on the contrary they continue to develop . 
Security Needs as Reflected in the Poetry of Rich, Giovanni, and Silko

The three poetesses under study are brought up among caring parents who provide them with a good standard of living, a great deal of education, and the required security to think of higher needs. Yet, they know that indigent people and the minorities in the American society are exposed to several forms of insecurities that threaten their lives and thwart their dreams, such as male domination, white oppression, violence, rape, racism, and other anxieties. Consequently, they strive to reflect their problems and satisfy their needs. They aspire to attain equal rights for their people and make them feel safe and satisfied in the American society. Since Rich, Giovanni, and Silko seek self-actualization, they reflect some of the forms of such abuses in their poetry to adjust their conditions and become powerful to achieve higher goals in life .

Rich lived in a quiet atmosphere, but she was irritated by male domination which surrounded her. She was a good wife, a decent mother, and a great poet, yet she suffered from her domineering father and husband who exercised an excessive patriarchal control upon her life. Consequently, she highlighted in her earlier poetry the issue of patriarchy that diminished women's voice and authority. In her essay "Anti-Feminist Movement," she states that patriarchy is a " kind of group organization in which males hold dominant power and determine which part females shall 
and shall not play, and in which capabilities assigned to women ... are excluded from the practical and political realms" (qtd.in Langdell 60). She sees that aspirations and dreams of women are always obstructed in a patriarchal culture. She expressed this idea in her first collection of poetry in 1951, A Change of World, but at this time there was no strong women's movement. In this regard, Kristin Lynn Stoner states: "Because of this, she had no specific audience or feminist goal in mind when writing her earlier poetry" (4). Considering her poetry as an outlet of women's suppressed thoughts, Rich reflects women's contempt and fury at forms of insecurity that confront them in society .

Rich reflects the insecurity and excessive patriarchal control of white men over women. In her poetry, she shows the male domination inflicted on women, and she presents women who try to survive and overcome their hard situation. "Aunt Jennifer Tigers" (1951), for example, presents the life of a disempowered woman who is oppressed by her domineering husband, but she escapes from her tough life through a work of art. In his article "Aunt Jennifer: A Victim of Patriarchal Society," G. Dhanya remarks: "The poem "Aunt Jennifer's Tigers" explores the controlled condition of women with all its possibilities of challenging the patriarchal gaze upon the women" (75). The poem opens with the protagonist, Aunt Jennifer, performing needlework and sewing images of tigers onto a tapestry. In the first stanza, 
the speaker describes the tigers in a highly symbolic and visual scene. The "tigers prance across a screen, / Bright topaz denizens of a world of green" (1-2). The lively description of the tigers and their "topaz" color, which is wine-red, orange and yellowy, along with their impressive movements express their fearlessness. The use of the color "green" reveals Aunt Jennifer's dream of a happier life. Then, the speaker continues his description of the fearless tigers. He states that they are not afraid of "the men beneath the tree" (3). The tigers are so brave that they could "pace in sleek chivalric certainty" (4). By personifying the tigers as "chivalric" knights, Rich reflects the bravery and power of the tigers .

Though the speaker does not provide any information about Aunt Jennifer's husband, it seems that he affects her emotional state negatively. In the second stanza, the speaker describes Aunt Jennifer while sewing the tigers on her tapestry. Aunt Jennifer's fingers are "fluttering through her wool" (5) and this makes "the ivory needle hard to pull" (6). Her fluttering hands are a sign of anxiety and distress. The speaker ventures to speak about this helpless woman. $\mathrm{He}$ states: "The massive weight of Uncle's wedding band/ Sits heavily upon Aunt Jennifer's hand" (7-8). The "weight of Uncle's band" is a metonymy of the burdens of marriage and male domination that circumscribe Aunt Jennifer's life. The hyperbole in the word "massive" emphasizes the unhappiness of Aunt Jennifer. In the final stanza, the speaker indicates that when Aunt Jennifer dies, "her terrified hand will lie/ still 
ringed with the ordeals she was mastered by" (9-10). These lines suggest that Aunt Jennifer will not escape from her troubles even after her death. The passive form of "ringed" evokes that she is forcefully indulged in this tough marriage. The "ordeals" refer to the domestic chores imposed on her, and the verb "mastered" connotes that Aunt Jennifer seems to be a slave who obeys the orders of her master. In the closing lines, the speaker states: "The tigers in the panel that she made/ will go on prancing, proud, and unafraid” (11-12). By using the adjectives "proud" and "unafraid", Rich contrasts the bravery of the tigers with the powerlessness of Aunt Jennifer. In his article "Adrienne Rich: Vision as Rewriting," Thomas B. Byers proclaims that the tapestry on which Aunt Jennifer has knitted tigers symbolizes the values that Aunt Jennifer represses, such as: strength, assertion, fearlessness, and fluidity of motion (145-46). The poem also signifies that Aunt Jennifer will always be remembered through her art, which is a means of self-assertion in the patriarchal culture she lives in .

Rich deals with other forms of instability that face women in society, such as disintegration of families and lack of communication. As an example, "Living in Sin" (1955) is a twenty-six-line stanza poem that significantly depicts the stark contrast between a young woman's romantic notion of her marital life and the bitter reality of her daily routine. In other words, it presents her transition from daydreams to the 
heavy domestic chores. The poem begins in the past, with a woman who thought she would have a perfect life with her husband. She thought that daily life chores such as cooking and cleaning would not be a part of her life. The speaker states: "She had thought the studio would keep itself; / no dust upon the furniture of love" (1-2). These lines reflect her naivety for simply imagining a romantic ideal of her life. Langdell clarifies that the opening lines of the poem "set the tone for a poem about the domestic stresses brought on by entering fully into a passionate relationship out of wedlock" (31). The poem shifts to the woman's current life of the leaky faucet, dirty windows, and noise. Then, it moves to her romantic illusions as the woman imagines a pretty picture of her home: a "plate of pears,/ a piano with a Persian shawl" (4-5), and a cat. The alliteration of plosive p's stresses aristocratic luxury. This sharply contrasts with the nasty details of her morning: the "scraps/ of last night's cheese" (10-11), the three "sepulchral" (11) bottles left by her husband, and the insects in her kitchen. The short choppy lines throughout the poem signify that the woman's life sounds chaotic and miserable .

The diction of the poem reinforces the depression and alienation of the woman in the poem. The negative connotations of "writhe," (8), "tramp," (9) "coldly" (10), and "sepulchral" (11) take the woman out of romantic dreams and place her in the grim reality of her current life. The poem 
switches to the woman's counterpart who is introduced in four choppy lines as follows:

Meanwhile, he, with a yawn, sounded a dozen notes upon the keyboard, declared it out of tune, shrugged at the mirror, rubbed at his beard, went out for cigarettes. (15-18,

In these lines, the poignant caesuras assure the discontinuity of this love relationship between the married couple. The speaker's lover is yawning; this reflects that he neglects her and goes on with his self-absorbed life. He then plays the piano which is out of tune like his relation with his woman. Next, he shrugs at the mirror and leaves for a cigarette, an action that suggests his indifference to his wife. Langdell points out: "The succession of active verbs describing him indicates his edgy restlessness, followed by his escape and his angry dynamism, powerlessness to keep him in" (32). Thus, for the woman persona, this romance has become a sin and a lie.

After reflecting on the security needs for women in Rich's poetry and showing how she strives to bring them to light, this level in Giovanni's poetry will be discussed, too. Actually, Giovanni follows the same path of Rich as she highlights the security needs in her poetry, but she focuses particularly on poverty, racial segregation, and marginalization that face African-Americans. AfricanAmericans need to feel that their life is secured in the white 
culture; they seek to be treated equally with their white counterparts in politics, jobs, education, housing, and other areas. When safety needs are satisfied to some extent, they could move to the satisfaction of higher needs. In the late Sixties and early Seventies, Giovanni addresses herself more to the social and political milieu of her people in the American society. In her poetry, she reflects the suffering of African Americans as they are subjected to racism and poverty that threaten their life. She shows that they are treated as suppressed human beings, having no rights of equality or freedom .

Giovanni's early poetry presents a social commentary on the dire poverty and racism as main features of insecurity which afflict the lives of African-Americans. For example, "Nikki Rosa" (1968) recalls the childhood of a young black girl at times of racial discrimination and poverty. Nikki, the narrator, states: "if you're Black/ you always remember things like living in Woodlawn/ with no inside toilet" (2-4). Marie Elaine Shouse points out that Nikki "recalls the social and economic condition of her childhood and through these images creates a strong identity with her economically lower class black audience" (130). As the poem continues, the narrator claims that if a Black American becomes popular, white biographers will only memorize his poverty, but they will "never talk about how happy you were to have/ your mother/ all to yourself' (6-8). In these lines, the poetess reflects that strong family bonds unite black people during 
hard times. Then, the narrator reflects that white biographers will never mention warm baths given in "one of those/ big tubs that folk in Chicago barbecue in" (10-11). Clearly, the poetess combines the use of images with blunt word combinations to make her point: she compares the miserable situation of her people to the luxurious life of the white American folks. A little further, the poem clarifies that the white American society is inhospitable for the dreams of poor African-Americans. The narrator elaborates: "your biographers never understand/ your father's pain as he sells his stock/ and another dream goes" (17-19). These lines denote to the Black Americans' great migration to the north where their dreams of owning houses are thwarted by discrimination and oppression. African-Americans will be continually oppressed unless they struggle for their rights zealously .

Similar to Rich, Giovanni shows that the relationship between men and women lacks communication, cooperation, love, care, and even support, in the black American community. While black women hold the entire responsibility of their families, black men are careless and underestimate women's efforts. In "Woman" (1978), as an example, Giovanni extensively uses imagery and symbolism to depict the numerous futile attempts of a black woman who tries to communicate with her husband, reaching to a superb moment of self-realization at the end. The poem shows the absurd attempts of a woman who tries to mold herself to fit 
the needs of her lover. The poem opens with a woman character expressing her wish "to be a blade/ of grass amid the fields" (1-2), but her lover refuses to be "the dandelion" (4). This imagery connotes that she wants her lover to support her and be the consolation in her life, but he puts her down. Next, she declares her wish to be "a robin/ singing / through the leaves" (5-7), but her man rejects to be "her tree" (9). The "tree" stands for support, strength, stability, and reliability, which are missing in the life of this woman. Having failed to attract his attention, she decides to be a spider. The narrator states: "she spun herself into a web/ and looking for a place to rest" (10-11). However, the man "stood straight" (13) and refused to be her shelter .

The poem is rich with such metaphors to reflect how hard this woman tries to please her husband, but in vain. The man's continuous rejection of his wife is a proof of his arrogance and unkindness. Consequently, the woman gains awareness and eventually realizes that she can only be herself. The narrator states: "She decided to become / a woman" (1920 ). This means that she decides to move forward in life, to create her own identity, and to conquer her weakness. Abney Louis Henderson indicates that the extensive use of imagery in this poem connotes that "Giovanni is against fitting the mold, because she believes the individual woman must mold her own identity and act out her responsibilities to such an identity" (65). Giovanni knows that the feeling of security 
will not be fulfilled for women unless they struggle hard against male domination .

In order to deal with how Silko addresses the security needs of her people, we have to give a brief account of the occupation of the lands of Native Americans by the European settlers. Native Americans are a group of ethnic minorities in the United States of America discovered by Christopher Columbus, the so-called discoverer of the continent of America. Spaniards, Anglo-Saxons, and French people came and asserted the right to occupy the lands of the Natives. Over three hundred years of occupation, the Indian tribes were eliminated to the status of domestic dependent nations deprived of their rights of freedom and equality. William C. Canby states that it was not until the twentieth century that the Indians were given civil rights owing to the Indian Citizenship Act issued in 1924 and Pan-Indian Movements in 1960s (16-23). Ironically, they were given civil rights generally because of the treaties held between the Indian tribes and the federal government, which entailed that Indians had to relinquish large portions of their ancestors' lands to the white settlers to set their industries .

The corpus of Silko's poetic works concentrates on the alienation of Native Americans in the white culture and the importance of native traditions to help them cope with modern life. Silko resists the white domination on Native Americans and reflects the forms of oppression and injustice 
perpetrated on her people. Silko reflects the injustice of white men towards Native Americans in "Toe'osh: A Laguna Coyote Story" (1981). In this poem, the poetess gives a synopsis of the history of white intrusion over the lands of Native Americans as follows :

Some white men came to Acoma and Laguna a hundred years ago and they fought over Acoma land and Laguna women, and even now some of their descendents are howling in the hills southeast of Laguna (26-29(

The lines depict the white oppressors as abusers of the earth and its inhabitants. The white men ravage Acoma and Laguna Pueblos for their land and women. In fact, these lines imply an eco-feminist perspective as they draw a connection between the oppression of women and the exploitation and destruction of nature. In his article "Leslie Marmon Silko: Toward an Eco feminist Future," Matthew Teorey manifests that Silko identifies the dominant white patriarchal culture as the source of the world's social and ecological problems (34). Silko's rage against the subjugation of the Native Americans is consistent with eco-feminists' concern for the liberation of all subordinated others. Later in the poem, the narrator introduces Charlie Coyote as a symbol of the abusive white men who spread chaos in the lives of Native Americans. Coyote wishes "to be governor" (30), and he declares that "when he got elected/ he would run the other men off/ the reservation" (31-33) and possess their wives. The poem 
continues to reflect the corruption of white politicians at Laguna. The narrator states: "They went door to door with hams and turkeys/ and they gave them to anyone who promised/ to vote for them" (38-40). As long as the security needs are addressed in the poetry of Rich, Giovanni, and Silko, it is now possible to move to the level of belonging and love needs.

Satisfying the Belonging and Love Needs in the Poetry of Rich, Giovanni, and Silko

Rich, Giovanni, and Silko seek to satisfy the belonging and love needs for themselves and for their people, as they realize that this prompts them to develop and attain 'self-actualization'. The poetesses engage in the search for such needs, but each behaves in her own way. Whereas Rich reconstructs her identity and satisfies her belonging and love needs in the company of women and children, Giovanni finds redemption in creating bonds with her family and the Black American community, and Silko finds a satisfaction for such needs by relating to nature .

Rich satisfies her belonging and love needs after going through a long stage of self-discovery and selfreconstruction. Maslow proclaims that in the level of belonging and love needs, the person seeks to find a place within his family or a group, and that is what Rich accomplishes in the forthcoming stage. She enters the real world defining herself beyond her prescribed roles as a wife 
and a mother. Rich, at this stage of her life, realizes that she has to reconcile what she is (a poet), with who she is (a woman), where the two identities intertwine, creating for her "a new language capable of embracing female energy and creativity" (Keyes 49). Rich's stage of self-reconstruction of her identity is expressed in her poetic volume Necessities of life (1962-1965). She "moves steadily to inhabit the world and to establish contact with that self which was largely suppressed and almost forgotten" (Kaushal 75 .)

In her poem "Necessities of Life", Rich speaks through the voice of a woman, declaring: "Piece by Piece I seem / to re-enter the world: I first began" (1-2). "Piece by Piece" indicates that she is broken and emotionally drained over trying to be herself. This can be considered as Rich's peak experience of transformation as she announces her reentrance into the world of poetry that she has left before, leaving the confines of domesticity aside. Looking back at her old self, she views herself as a "small, fixed dot" (3) and "a dark-blue thumbtack/ pushed into the scene" (4-5). Through this significant metaphor, the poet reveals that her earlier life is insignificant; this is because of the exterior forces that exhaust her: male chauvinism and domesticity. The color "dark-blue" evokes her depression and agony. A little further, she states: "Now I was hurriedly/blurring into ranges/ of burnt red, burning green," (11-13). Rich has made her way into the poetic world with a quiet strength, but she is "blurring". Shelby Lynette Scruggs explains that the woman 
character is representative of Rich who "has found her creation - poetry - but where to express it perplexes her. No domain exists for a female poet because women have only been allowed to exist primarily as a wife and mother" (17). Yet, Rich continues her struggles to prove her worth as a powerful poetess in the male dominated society .

Later in the poem, Rich realizes that she is nearly consumed, and she decides to be herself. Through a poignant metaphor in which the poetess likens herself to a "dry bulb / thrown into a cellar" (22-23), Rich reveals that frustrations, unfulfilled dreams, and futile aspirations are the essence of her life. The external world becomes threatening to her, so she decides to shape her identity and prevent others from directing her life. She declares: "I used myself, let nothing use me / like being on a private dole" (24-25). She declares that she will not permit anybody to exploit her. These lines signify her ongoing process of becoming a self-actualized person. She prefers privacy for some time to develop her own abilities and face life challenges. As the poem develops, the poetess speaks about the possibility to re-enter the poetic world again and face life challenges boldly. This idea is expressed through a poignant metaphor in the following lines: "trenchant in motion as an eel, solid / as a cabbagehead" (29-30). This expressive metaphor suggests Rich's growing sense of power and self-esteem. Throughout the poem, the use of the words "first", "now", "till", and "soon" 
indicates Rich's ongoing process of self-reconstruction and development.

Continuing her search for her true identity, Rich likens her talent as a poetess to a "helicopter" that moves in the sky rashly, but it finally comes back to its right destination with a new identity. She writes in her poem "In the Woods:" \begin{tabular}{rrrr} 
My soul, my helicopter, & whirred \\
distantly, & \multicolumn{2}{c}{ by } & habit,
\end{tabular}

only to find it all going differently for once this time: my soul wheeled back and burst into my body. (30-31, 41-44 (

The metaphor of the helicopter signifies that Rich's identity is lost when she imitates "by habit" the male poets from whom she has learnt the craft of writing poetry. The line "my soul wheeled back" suggests that she decides to be herself, leave imitation, and create her own identity as an independent woman poet who has her own style and themes. In truth, Rich continues her poetic career with a new spirit and with a determination to face life in her own way.

After reconstructing her own identity, Rich realizes that her belonging and love needs are only satisfied in the company of women and children. In her ten-part poem "Phenomenology of Anger" (1973), Rich identifies herself with the woman speaker, stressing : 
The only real love I have ever felt was for children and other women. Everything else was lust, pity, self-hatred, pity, lust.

This is a woman's confession. (109-113(

In these lines, the woman speaker openly expresses her love for women and children, while she confesses her contempt towards males. The repetition of "lust" and "pity" stresses the tone of honesty in the poem as Rich proclaims that, except her love for women and children, all the other emotions she feels are lust and pity together with despair or hatred of self. Linking lust and pity together suggests the intensity of the speaker's frustration and her eagerness for love. Moreover, it implies the poetess's rage at the sexual exploitation of women at the hands of men who only serve their personal purposes. The last line carries a poignant feminist tone.

Giovanni, unlike Rich, does not spend much time to satisfy her needs for belonging and love. Her feelings of belonging to the black community and love for blacks are very strong from the very beginning due to the effect of 'Black Arts Movement' and 'Black Power Movement' on her thoughts and perceptions. She defines herself in terms of two principle factors that are closely related: power and love. Giovanni initiated her poetic career in1969 as a black revolutionary poet and political activist who fights for the 
rights of Black Americans. She fulfills her need for belonging by celebrating, in her poetry, black values, such as black power, black solidarity, and black love. In Gemini, She declares: "I am a revolutionary poet in a prerevolutionary world .... And dealing with Blackness as a cultural entity can only lead to revolution" (60). She contends that blackness relates to power, collective identity, and the social authority of self-determination. Therefore, she uses her poetry to exhort black people to rebel, retaliate, and assert their black identity .

Through her early poetry, Giovanni shows a maternal responsibility towards her people who are subjected to the sexist and racist policies of the dominant white culture. She speaks for her people, dealing with the social issues that affect them. Her poems in the first three volumes of her poetry Black Feeling, Black Talk (1968), Black Judgment (1969), and Re-creation (1970) refer to her people's social needs which are revolutionary and political at the same time. In a number of poems in such volumes, she discusses the inevitability of black revolutions to react against injustice and oppression inflicted upon black people by the racist whites. Indeed, Giovanni is a Marxist as her poems call for revolutionary communism and seek to achieve equality. She develops the racial awareness of her people as she instructs them to alter the way they behave in the racist society where they live. Michelle J. Pinkard writes: "Giovanni's poems always challenge the historical survival method of submission 
or a compliant reaction to oppression in favor of the more contemporary, proactive, and even rebellious approaches to fighting injustice" (11). In a number of poems, Giovanni pronounces that violent revolutions are the only way for Black Americans to put an end to their exploitation by the racist whites and get the belonging and love they need. Actually, she promotes such a belief shortly after the assassination of prominent Black American leaders who struggle fiercely against racial segregation, namely Malcolm X, Martin Luther King, jr., and Medgar Evers. The killing of those heroic figures affects her thoughts and directs her towards bloody and violent actions. R. Roderick Palmer explicates that Giovanni displays "the open, revolutionary temperament of the aggressive activist. She has little patience with slow change, and exhorts Black Americans to rise up and take arms" (35). As a result, in her poetry, she instills her people to wage a war against the suppressive White Americans and make violent revolutions to demolish America's corruptive governmental system with its social, political, and moral values .

In "The True Import of Present Dialogue, Black vs. Negro" (1968), as an example, Giovanni provokes black people to rebel against white racism and belong to their black identity. In Black Women Writers (1984), Mary Evans remarks that the poem embodies not only the literal demand for the killing of white oppressors, but also "the symbolic 
need on the part of the blacks to kill their own white values" (220). The poem's title is expressive; it incarnates the divergence of conflicting attitudes among black people during the 'Civil Rights Movement': the blacks who have a revolutionary spirit, and the Negros with a more bourgeois mentality. In the opening lines, Giovanni addresses a black man, using abusive language. She states: "Can you kill/ Can you kill/ Can a nigger kill a honkie" (2-4). These questions draw the reader's attention to the uncertainty of the poetess about the ability of the negro to kill his enemies as he is brainwashed, conforms to white standards, and accepts his degradation at the hands of the racist whites. Later in the poem, Giovanni asks "a nigger" (5) if he can "stab-a-Jew" (11), "run a protestant" (14), or "piss on a blond head" (18). To Giovanni, black people must take revenge on the white man and those who have assisted him in his war against the black race. Moreover, she sees that they should kill the American Jews who share in the economic exploitation of the poor black ghettoes. As the poem proceeds, the speaker states boldly: "Can you kill the nigger/ in you/ Can you make your nigger mind/ die" (29-32). To attain freedom from the continual persecution by the white oppressors, the blacks have to discard certain values, actions, and habits which take them away from their black identity. By using the offensive term "nigger" repetitively, Giovanni tries to change their consciousness and force a positive change on them. Later in the poem, she exhorts the blacks to "splatter the brains" (40) 
of the whites, and she urges black women to "lure them to bed to kill them" (42). The harsh language of the poem and the resonance of lexical terms, such as "kill", "piss", "strangle", and "stab" underscore the revolutionary stance of the poetess during the 1960s .

In other poems, Giovanni overstresses the idea of perpetuating punitive violence on the white oppressors to gain identity and belonging. In her poem "Records" (1968), she persuades black people to share in the destruction of the American racial system and forming their black identity. Again, she adopts the negative idea of violence in her quest for the freedom of her people. The poet declares :

this

country

must

be destroyed

if we are to live must be destroyed if we are to live must be destroyed if we are to live. (41-45)

In these lines, Giovanni experiments with the form. She uses cubist cyclic technique, which is evident in repetition and the lack of punctuation. Through setting off the second line, the poet draws emphasis to the word "destroyed". In doing so, the poetess is anarchist; she denotes to George E. Kent's motif of construction within destruction, picturing a "healthy America arising from violent destruction and rebirth" (216). The refrain of "must be destroyed" is an assertion that violence is an effective means of change for 
Black Americans. This idea is emphasized through the structure of the lines; the omission of the punctuation marks gives the effect of velocity and accentuation, thus conveying the urgent need to resist oppression.

Giovanni calls for the satisfaction of one's belonging and love needs in the sphere of the family and the community as well. She diverts her attention from the militant issues of her country to personal ones, showing a great interest in the affairs of the family. In her poems, Giovanni reflects the different forms of love, including the love of parents for their children and the love between the spouses. In her poem "Love Is" (1983), she gives a detailed description of mothers' love for their children and spouses. She elaborates: "Some people forget that love is / tucking you in and kissing you/ 'Good night'/ no matter how young or old you are" (1-4). Mothers spend their lives "listening" (7) to the complaints of their kids, "laughing" (7) at their jokes, and "asking/ questions" (8-9) regarding their daily life matters. Furthermore, they tolerate hard house hold chores and look after their families out of love. The poetess proclaims: "Few recognize that love is/ commitment, responsibility/not fun at all" (11-13

Giovanni also writes several biographical poems that reflect her satisfaction of the need of love. In "Knoxville, Tennessee" (1968), for example, Giovanni reminiscences on her pleasant childhood memories with her family. She talks about the pleasures of the summer season in Knoxville, 
Tennessee. She expresses her lovely moments at her father's garden when she eats "fresh corn" (3), "okra" (5), "greens" (6), and "cabbage" (7). In addition, she listens to "gospel music "(14) and goes "to the mountains" (13) with her grandmother. This descriptive poem strongly appeals to the senses, bringing to mind delicious food and the tranquility of nature. Yet, it possesses qualities that reveal the warmth and togetherness in the family life. In another poem titled "For Tommy" (1970), Giovanni expresses her love for her son, and she reflects that his birth has entirely altered her life. She states:

$\mathrm{He}$

defined

my

nature

and gave

me

new

name

(mommy)

which

supersedes

all

others

controls

my

life

and

makes

me

glad

that he does. (6-11)

Enjambment lends energy to the poem and denotes to Giovanni's enthusiasm and happiness with her maternity. The use of active verbs, such as "defined", "gave", "controls", and "makes" boosts Giovanni's self-definition. The insertion of her new title "mommy" indicates her excitement for being a mother. Moreover, the different metrical pattern and varied lengths of lines parallel the change in the poetess's life and the fulfilment of her need for love. 
As long as the belonging and love needs are illustrated in Rich and Giovanni's poetry, we can now address such needs in Silko's poetry. Silko's satisfaction of the belonging and love needs in the Native American community is more complicated than that of Rich and Giovanni. This is due to the fact that Native Americans suffer from 'Double Consciousness' because they live on the border of two cultures: the mainstream American culture and the Native American culture. Actually for the Indian of mixed ancestry, the search for an identity and acceptance in society are crucial matters. Silko talks about her identity dilemma; her mixed blood origin, and she clarifies how it affects her status in the Indian and non-Indian world. She states: "At the core of my writing is the attempt to identify... what it is to grow up neither white nor fully traditional Indian. It is for this reason that I hesitate to say that I am representative of Indian poets or Indian people, or even Laguna people. I am only one human being, one Laguna woman" (qtd. in Seyersted 35). She is keen on creating a strong bond with her Indian culture. It is only through connection with her heritage that she manages to stand against white racism, satisfy her need for belonging, and prove herself as a prominent Native American poetess.

Silko finds that her needs for belonging and love can be realized through maintaining strong ties with nature, land and animals. This is an eco-feminist approach, which shows concern and love for nature. Edith Blicksilver, a critic, points 
out: "The relationships between human beings and natural forces, the animal and the vegetable kingdoms, are subjects of a series of poems describing different types of love relationships" (156). In her poetry, Silko shows that nature is a friend, not a foe of man. Teorey proposes that her culture's relationship with the natural landscape is one of the considerate spiritual and physical interconnectivity (31-32). For example, "Lullaby" (1981) reflects a maternal relationship between the land and human beings through a mother's voice. The poem opens as follows :

The earth is your mother,

she

holds you.

The

sky

is

your

father,

he

protects

you.

Sleep,

sleep. (1-6

Nature seems as if it were a family that protects its members and embraces them till their death. According to a Navajo tradition, the earth is a mother figure that cares for humans. The repetition of "sleep" emphasizes that nature is a source of a shelter from danger and a relief from pain. Then, the speaker states: "Rainbow is you sister,/ She loves you./ The winds are your brother" (7-9). The personification together with the rhymed couplets and the punctuation marks reinforce this bond and strengthen the tie between 
people and their land, thus emphasizing the need for love and belonging, but in nature. Mary McBride points out: "The earth, the sky, the rainbow, the winds, and the people (we) in the poem, are always together in the spirit realm, where lies the eternal essence of life" (15.)

The theme of love extends to include Native Americans' intense love for animals and satisfaction of love. In “The Time We Climbed Snake Mountain” (1981). The poem's subject is about a person who climbs Snake Mountain with some of his friends, thoughtfully warning them not to step on a snake. The speaker states: "I grab the warm parts of the cliff / and I feel the mountain as I climb" (3-4). While climbing the mountain, he discovers that a "yellow spotted snake is sleeping on his rock" (6). In a thoughtful warning voice, the speaker states: "watch out, / don't step on the spotted yellow snake/ he lives here" (10-12). Actually, the speaker does not want to disturb the peace of animals, for he sees that animals have the right of living just as human kind.

The Esteem Needs as Expressed in the Poetry of Rich, Giovanni, and Silko

Satisfaction of love and belonging needs prompts the emergence of esteem needs for the three poetesses under analysis. An individual needs to know what he or she is capable of doing and mastering in life. Once this is recognized, the esteem needs can be fulfilled, as Maslow explains. Rich, Giovanni, and Silko set their goals and move 
on to attain them irrespective of challenges in their lives. They make decisions to satisfy their needs of independence, competence, confidence, and freedom. Through their poetry, they make significant changes in the lives of their people. As a result, they gain attention, appreciation, recognition, and dominance in society .

Rich has high self-esteem both as an independent woman and as a poetess. Her feeling of self-esteem is prominent in Diving into the Wreck (1971). In this volume, she writes a number of poems that reflect her esteem for being an independent woman poet, getting rid of the constraints of marriage. This personal experience greatly affects the subject matter of her poetry; she celebrates the independence of women from the conventional roles imposed on them by male-dominated societies. In "From a Survivor" (1971), as an example, Rich encourages women to struggle against the conventional roles set by the patriarchal society and combat male domination. She identifies with the poem's speaker, recalling the memory of her marital life. She and her husband believed that they were "special" (9) partners who could overcome the difficulties of marriage and have a perfect life with no faults. The speaker states: "I don't know who we thought we were/ that our personalities/ could resist the failures of the race" (3-5). She and her husband thought that they had the ability to get over the difficulties that affected their long term relationship, which Rich points 
to as 'the failures of the race'. Scruggs explains: "Rich recognizes that women's oppression is not the fault of any individual man, but the fault of a patriarchal system" (38). As the poem continues, Rich states that she realized that she and her husband were "Like everybody else" (9); their marriage is like the bond of ordinary people who are liable to faults of their own .

Rich uses the speaker of the poem to reflect her own thoughts and ideas. Rich's confidence and independence develop after the death of her husband since she is not worried about being dominated by him or by any other man. She no longer thinks of her husband as "the body of a god/ or anything with power over my life" (15-16). The lines clarify Rich's refusal of considering women as men's possessions. In the concluding lines, she declares that she is living "now a succession of brief, amazing movements/ each one making possible the next" (23-24). These lines are an evidence of Rich's self-esteem and her progress toward 'selfactualization'. She pronounces that each moment of her new life - as a divorced and an independent woman - gives her the chance to step forward to the next stage successfully.

Rich also shows esteem for others in many poems; she honors the courage possessed by famous women till the moment of their death. To cite an example, the poem titled "Power" (1978) is about Mary Curie who devoted her life to science. Curie was a renowned woman scientist whose work both enhanced and, ultimately took, her life away. She 
discovered radium, but the element poisoned and killed her. Curie insisted to continue her experiments though "she suffered from radiation sickness/ and her body bombarded for years by the element / she had purified" (7-9). Though the radium, that Curie succeeded in separating and purifying, caused her sickness, she never regretted its fatal consequences. Curie was a symbol of power, courage, autonomy, selfdependency, and creativeness. She persisted to carry out her work neglecting "the source of the cataracts on her eyes/ the cracked and suppurating skin of her finger-ends" (11-12). She held on till she became unable to "hold a test tube or a pencil" (13). The lines show how Curie sacrificed her life for a cause she believed in. Curie's great sacrifice is shown as an act of honor to endorse a true role model to the women of the upcoming generations. In the closing lines, Rich remarks that Curie died a popular woman "denying / her wounds came from the same source as her power" (16-17). Scruggs remarks that "Rich leaves physical space between words to show that what gave Curie power also killed her; similarly, in a patriarchal culture, what some women actually think gives them power - men - actually destroys them” (42). Indeed, the poem implies that women can make significant achievements, hold responsibility, and tolerate their physical pains to reach their goals.

Much like Rich, and even more, Giovanni struggles to meet her esteem needs. No doubt, ethnic groups should be 
conscious of their self-worth and acknowledge their pride in their races in order to pursue their battle against the white oppressors. Giovanni's self-esteem stems from her racial awareness of her identity as a black woman poet. In "My Poem” (1968), she professes: "i am 25 years old/ black female poet" (1-2). These lines assure her feelings of pride in her black female identity. This happens soon after the emergence of black feminist struggles that invoke black women to assert their own identities, revolt against submission, and subvert their miserable conditions. In another poem titled " $\mathrm{My}$ Muse", she reveals her pride in her poetry, confessing that her basic inspiration comes from her own writings. She openly declares :

I am

my

own

Muse

I

delight

me

With

my

words

Of

both

wisdom

And wit (1-6(

Clearly, Giovanni sees that she can guide people by her insightful thoughts and witty advices. The use of the selfassertive pronoun "I" and the repetition of the possessive pronoun "my" emphasize her self-esteem and confidence in her abilities. The use of enjambment indicates her full energy and enthusiasm when she writes poetry .

Giovanni's esteem for black poets, artists, and black heroic figures boosts her pride in being a Black American. 
She is proud of her ancestors' robust struggles against racial oppression since the late Sixties. She praises the courage, determination, strength, and unity of her people for their unending struggles against tyranny and injustice in the American society. In her first three volumes of poetry, she wrote a number of poems dedicated for black poets, artists, and revolutionaries who benefited the humanity with their revolutionary poetry. Giovanni felt that the long struggles of black heroes should be highlighted and their courage should be applauded to preserve their identity and position in society. In a number of poems, Giovanni applauds heroic figures for raising the awareness of their fellow beings concerning their oppression by the white people.

In her poems that echo her appreciation for the revolutionary spirit of the blacks in the Sixties, she commemorates Dr. Martin Luther King in a poem titled, “The Funeral of Martin Luther King, Jr." (1968). In seven lines, Giovanni gives the readers a quote from the headstone and from Martin Luther King's "I Have a Dream: speech". The poem opens as follows: "His headstone said/ FREE AT LAST, FREE AT LAST" (1-2). These lines link the poem directly to King's speech and lead to the study of the historical background beyond his death. King was assassinated because of his struggles against racial segregation perpetuated upon black people in America at the hands of white oppressors. He "preached non-violence" (7) and called for 
the freedom of black people from the constraints of oppression and racism. His "death is a slave's freedom" (3). His assassination irritates black people and forces them to fight for their freedom .

Like both Rich and Giovanni, Silko knows her full power, self-worth, and status in the Native American community, which gives her esteem both for herself and the others. Silko has made many contributions that have established her reputation as a significant Native American woman poet. She establishes a voice of authority and authenticity for herself and for Native Americans. She regards her writings as a continuation of an existing oral tradition within the Laguna Pueblo people. Similar to Rich and Giovanni, she celebrates the achievements of her people; she celebrates and immortalizes Native American mythic figures of the past, some of which are Yellow Woman, Arrow Youth, Mother Earth, and Spider Woman or Thought Woman. Such characters are characterized by their daring adventures and supernatural powers, which attract and heal Native American people. She writes: “Old Spider Woman... has always helped the people whenever they faced great difficulties" (Storyteller 141). As an example of her esteem for the legendary characters in her culture, her narrative poem “Trickster Medicine Man” (1981) honors the Mother Earth who punishes some Laguna Pueblos because they believe the tricks of a Medicine Man who performs magic at a house and convinces the inhabitants of a medicine that can improve 
their lives. Consequently, the Mother Earth gets angry and takes the rain clouds away. Therefore, "The wind stirred the dust./ The people were starving./ She is angry with us" (1-3). At last, people become conscious of their fault and declare: "We better send someone/ to ask for our forgiveness" (8-9). They send birds that serve as messengers between them and the Mother Earth, and finally "everything was straight again" (12). The poem's speaker contends that "the storm clouds returned/ the grass and plants started growing again" (14-15). In this poem, Giovanni celebrates the Mother Earth's power of ruling the universe .

Conclusion :

In conclusion, the analysis of the poetic works of Rich, Giovanni, and Silko shows that the three poetesses satisfy the deficit needs in Maslow's hierarchy. The poetesses live in an atmosphere where the physiological needs are fulfilled for most people. Therefore, they tackle in their poetry the higher needs in life. They reflect on the lack of security and the problems that face their people in their different communities, such as the lack of communication between lovers, loss of family ties, male domination, and suppression of women. Afterwards, they satisfy their belonging and love needs, but they act in different ways. Rich goes through stages of self-reconstruction and finally asserts her identity as an independent woman and a poetess. Besides, she yearns for love in her earliest poems and realizes 
it in the world of women and children, apart from the domineering men. Giovanni's love and respect for Black Americans satisfy such specific needs. Silko's strong connection to nature and respect for animals and natural surroundings are her ways of satisfying her needs for belonging and love. Moving to the esteem needs, the poetesses possess high self-esteem and show esteem for others. Their poetry reveals their personal strength, adequacy, achievement, independence, and freedom that boost their self-esteem. Besides, they show respect for the rewarded struggles of their people, including revolutionists, scientists, artists, poets, and mythic figures . 


\section{Not:}

${ }^{1}$ In the mid-Fifties, Rich got fed up with her defined roles as a wife and a mother. She states: "marriage and motherhood-experiences that were supposed to be truly, naturally, womanly, often left me feeling unfit, disempowered and adrift" (Blood 49).

${ }^{1}$ Fowler explains that when Giovanni's father tried to get a loan, racist banking practices made the dream impossible, so he sold the shares he had purchased to make a down payment on a home on Jackson Street in Lincoln Heights (Literary9-10).

1 The American Indian Movement, which initiated in the 1960s, succeeded in changing history. The Pan-Indian Movements, along with the appearance of the Indian Citizenship Act, developed literary writings that criticized the dominance of the mainstream American culture. Native writers and leaders cooperated together to gain power against the federal and state government. They insisted on struggling against prejudice at all levels.

${ }^{1}$ For further readings on Ecofeminism, see Greta Garrd's "Ecofemisnim and Wilderness", pp.5-24.

${ }^{1}$ She finds redemption in her relationship with her life partner, Michelle Cliff who gives her the needed feeling of being loved.

${ }^{1}$ Double consciousness is a theory coined by Du Bois referring to psychological challenge of reconstructing an African heritage with European upbringing in terms of slavery and education. 
${ }^{1}$ Though Native Americans are the original inhabitants of America, they are excluded from the mainstream society. Daina Miniotaite notes that in Silko's poetry the Native American is always portrayed "as a human being who has lost his conceptual identity due to the centuries old denigration of Indian culture, their discrimination, and constant westernization" (46).

${ }^{1}$ Native Americans closely connect with the natural world, regarding animals as equally distinctive and significant as human beings. They look upon animals as fellow creatures that share a common destiny with them; both live in the same society where they are affected by its developing conditions.

${ }^{1}$ This poem is written as a reaction to what she saw at Dr. King's funeral in Atlanta, Georgia. Nikki Giovanni was twenty-five years old in 1969; the year of Dr. King's assassination. During that year, Giovanni was graduated and wrote her second volume of poetry Black Judgment, which includes this poem. 


\section{Works-Cited}

Blicksilver, Edith. "Traditionalism vs. Modernity: Leslie Silko on American Indian

Women." Southwest Review, vol.64, no.2, Spr.1979, pp. 149-60. Jstor, www.jstor.org/ stable/ 43469156. Accessed 5 July 2017.

Byers, Thomas B. "Adrienne Rich: Vision as Rewriting ."World, Self, Poem:

Essays on Contemporary Poetry from the Jubilation of Poets, edited by

Leonard M. Trawick, Kent UP, 1990, pp. 144-52.

Canby, William C. Jr. American Indian Law. West Group P, 1981.

Dhanya, G. "Aunt Jennifer: A Victim of Patriarchal Society and a Persona

Evolving Conciousness of Modern Women- A

Study Based on Adrienne Rich's

Poem Aunt Jennifer's Tigers." IOSR Journal of Humanities and Social

Science, vol.20, no.12, Dec.2015, pp.75-79, http://www.iosrjournals.org/iosr-

jhss/papers/Vol20-issue12/Version4/J0201247579.pdf. Accessed 5 Sep. 2018.

Evans, Mary, ed. Black Women Writers (1950-1980): A Critical 
Evaluation. Anchor P,1984.

Fowler, Virginia C. Nikki Giovanni: A Literary Biography. Praeger, 2013.

Garrd, Greta. "Ecofemisnim and Wilderness." Environmental Ethics, vol.19. no.1,1997, pp. 5-24.

Giovanni, Nikki. The Collected Poetry of Nikki Giovanni: 1968-1998. Harper

Perennial, 2007.

---. Gemini: An Extended Autobiographical Statement on My First

Twenty-Five Years of Being a Black Poet. Penguin, 1976.

---. Love Poems. William Morrow, 1997.

Henderson, Abney Louis. "Four Women: An Analysis of the Artistry of Black

Women in the Black Arts Movement, 1960s-1980s." 2014. U of South Florida,

MS thesis. Shodhganga, shodhganga.inflibnet.ac.in/handle/10603/70752 .

Kaushal, Sanjeev Kumar. "A Critical Study of Adrienne Rich's Works in a

Feminist Perspective.” 2005. Aligarh Muslim U, PHD dissertation.

Kent, George E. A Life of Gwendolyn Brooks. UP of Kentucky, 1990. 
Keyes, Claire. The Aesthetics of Power: The Poetry of Adrienne Rich. U of

Georgia p, 1986. Google Books, books.google.com.eg./books?id

TJZi36MBs6UC\&printsec.

Langdell, Cheri Colby. Adrienne Rich: The Moment of Change. Praeger, 2004.

Maslow, Abraham H. Motivation and Personality. Harper and Row, 1954.

McBride, Mary. "Shelter of Refuge: The Art of Mimises in Leslie Marmon Silko's

'Lullaby."' Wicazo Sa Review, Vol.3, no.2, 1987, pp.15-17.

Miniotaite, Daina. 'Native American Literature:

History Revisited in Leslie

Marmon Silko's Ceremony. "Zmogus ir Zodis, vol. 10, no.3, 2008, pp.46-51.

www.ceeol.com/search/article-detail id= 70389 .

Accessed 10 May 2018.

Palmer, R. Roderick. "The Poetry of Three

Revolutionists: Don L. Lee, Sonia

Sanchez, and Nikki Giovanni." CLA Journal, vol.15,no.1, Sep.1971,pp.25-36.

Jstor, www.jstor.org/stable/44321527. Accessed 18 Aug.2018. 
Pinkard, Michelle J. "Nikki Giovanni and Water for my Garden.” 2005. Morgan

State U, MS Thesis.

Rich, Adrienne. Blood, Bread and Poetry: Selected Prose 1979- 1985. Norton,

1986.

---. Collected Poems 1950-2012: Adrienne Rich. $1^{\text {st }}$ ed.,

Norton, 2016.

Scruggs, Shelby Lynette. “American Journey Toward Female Equality With and

Through Adreinne Rich's Works.” 1999. Western Kentucky U, Master Thesis.

Seyersted, Per. Leslie Marmon Silko. Boise State UP, 1980.

Shouse, Elaine Marie. "An Analysis of the Poetry of Three Revolutionary Poets:

Don L. Lee, Nikki Giovanni, and Sonia Sanchez.” 1976. U of Illinois, Master thesis. IUCAT Kokomo, iucat.iu.edu/iuk/1648087.

Silko, Leslie Marmon. Laguna Woman Poems. Greenfield, 1974.

---. "lullaby." Poemhunter,n.d, www.poemhunter.com/poem/love-poem-91/ Accessed 20 Apr. 2018.

---. Storyteller. Little, 1981. 
---. "The Time we Climbed Snake Mountain."

Chicago Review, vol.24, no.4,

Spri. 1973, p.99. Jstor,

www.jstor.org/stable/25294773. Accessed 6 Feb.

2018.

Stoner, Kristin Lynn. "Daughters, Sisters, and Mothers:

the Poetry of Adrienne

Rich and the Next Generation of Female American

Poetics in the Poetry of

Kristin Stoner." 2003. Iowa State U, MS Thesis.

Retrospective,

lib.dr.iastate.edu/rtd/14447/.

Teorey, Matthew. "William Wordsworth and Leslie Marmon Silko: Toward an

Ecofeminist Future." Interdisciplinary Studies in

Literature and Environment,

vol.11, no.1, 2000, pp.31-56.

Jstor,www.jstor.org/stable/44086224. 